\title{
Relationships among GnRH, substance $P$, prostaglandins, sex steroids and aromatase activity in the brain of the male lizard Podarcis sicula sicula during reproduction
}

\author{
A. Gobbetti ${ }^{1}$, M. Zerani ${ }^{1}$, M. M. Di Fiore ${ }^{2}$ and V. Botte ${ }^{2}$ \\ ${ }^{1}$ Department of Molecular, Cellular and Animal Biology, via F. Camerini 1, 62032 Camerino MC, Italy; \\ and ${ }^{2}$ Department of Zoology, via Mezzocannone 8, University of Naples, 80134 Naples, Italy
}

\begin{abstract}
The release of $\mathrm{PGF}_{2 \alpha}$ and $\mathrm{PGE}_{2}$, progesterone, androgens and oestradiol in vitro, and the aromatase activity in the brain of the male lizard Podarcis sicula sicula during three different phases of the reproductive period were evaluated. In addition, the effects of salmon GnRH, substance $\mathrm{P}$, salmon $\mathrm{GnRH}$ antagonist, substance $\mathrm{P}$ antagonist, $\mathrm{PGF}_{2 \alpha^{\prime}} \mathrm{PGE}_{2}$ and acetylsalicylic acid on the release of prostaglandins and sex steroids and on aromatase activity in the brain were evaluated during the same three phases. PGF ${ }_{2 \alpha^{\prime}}$ oestradiol and aromatase activity were higher during the refractory phase, androgens during the fighting phase, and progesterone during the mating phase, while $\mathrm{PGE}_{2}$ was lower during the refractory phase. Treatment with salmon $\mathrm{GnRH}$ increased $\mathrm{PGF}_{2 \alpha^{\prime}}$ oestradiol and aromatase activity, but decreased the amount of androgens released. Substance $\mathrm{P}$ decreased $\mathrm{PGF}_{2 \alpha^{\prime}}$ oestradiol and aromatase activity, but increased the amount of androgens released. PGF $_{2 \alpha}$ increased oestradiol and aromatase activity, but decreased the amount of androgens released. Acetylsalicylic acid decreased PGF $2 \alpha^{\prime}$ oestradiol and aromatase activity, but increased the amount of androgens released. These data suggest that salmon $\mathrm{GnRH}$ and substance $\mathrm{P}$ have different roles in reproductive processes, with opposite mechanisms, in the central nervous system of this male lizard: salmon GnRH seems to be involved in regulating the refractory phase, while substance $P$ plays a role in regulating the fighting phase.
\end{abstract}

\section{Introduction}

The presence of salmon GnRH (sGnRH) (Powell et al., 1985, 1986) and substance $P$ (Lembeck et al., 1985; Bello et al., 1991) has been documented in some lizard species. These neuropeptides can act on gonadotrophin secretion and steroidogenesis in several species, including reptiles (Ciarcia et al., 1986; Varriale et al., 1986; Arisawa et al., 1990; Pitzel et al., 1991). This may not be true for all species since in some reptiles sGnRH is not present (Tsai and Licht, 1993) and since studies in vivo have shown that various forms of $\mathrm{GnRH}$ are inactive in some species (Licht and Porter, 1987). However, in other studies carried out in various organs of the anuran water frog Rana esculenta (Gobbetti and Zerani, 1991, 1992a, b) and the urodele crested newt Triturus carnifex (Gobbetti and Zerani, 1992b; Gobbetti et al., 1992), GnRH was found to induce an increase in the concentration of prostaglandins, which, in turn, regulated the secretion of sex steroids. These findings suggest that the stimulatory role of this neuropeptide on steroidogenesis is mediated by prostaglandins at least in some amphibians. In particular, Gobbetti et al. (1992) suggested that in Triturus carnifex the regulation of reproductive activity by the central nervous system depends on the relationships between $\mathrm{GnRH}$, prostaglandins and sex steroids.

Received 26 August 1993.
In reptiles, prostaglandins influence the expression of reproductive behaviour (Tokarz and Crews, 1981; Whittier and Crews, 1986) but nothing is known about the relationships among neuropeptides, prostaglandins and sex steroids in the central nervous system of reptiles. It is still unclear whether the lizard brain synthesizes or accumulates (or both) progesterone, androgens and oestradiol despite the demonstration of aromatase activity in the brain of several species (Callard et al., 1978; Zerani et al., 1992). De novo steroid biosynthesis has also been found in cultures of rat brain cells, which supports the concept that steroids are synthesized in brain cells (Jung-Testas $e t$ al., 1989).

In this study we compared the effects in vitro of substance $\mathrm{P}$, $\mathrm{sGnRH}$, an antagonist of substance $\mathrm{P}$, an sGnRH antagonist and prostaglandins on the release of prostaglandins and sex steroids by, and aromatase activity in, the brain of the male lizard Podarcis sicula sicula during reproduction.

\section{Materials and Methods}

\section{Animals}

The reproductive cycle of the male lizard $P$. s. sicula that lives around Naples (Campania, Italy, $25-75 \mathrm{~m}$ above sea level) is briefly described below. The annual breeding activity is 
restricted to spring. The gonads and the secondary sexual characteristics develop at the beginning of the spring and are functional until June, when a refractoriness to the still favourable ambient cues begins, followed by complete regression of gonads and secondary sexual characteristics (Angelini et al., 1980, 1981, 1986). The reproductive behaviour of the male is characterized by fighting behaviour in March and April and by mating in May (Ciarcia et al., 1986).

\section{Incubation in vitro}

Adult male lizards of this population were captured in April (fighting phase), May (mating phase) and June (refractory phase). Immediately after capture, the animals were killed by decapitation, the brains were rapidly removed and pituitaries were gently removed. The brains were placed in cold Dulbecco's modified Eagle's medium (DMEM; Sigma Chemical Co., St Louis, MO) containing $10 \mathrm{mmol}$ Hepes $1^{-1}, 1 \mathrm{mg}$ penicillin $\mathrm{ml}^{-1}$ and $2 \mathrm{mg}$ streptomycin $\mathrm{ml}^{-1}$, and transferred to the laboratory. For animals captured in each month, 110 brains were randomly and separately placed in wells of multiple tissue culture plates (Becton Dickinson, Clifton, NJ).

Each set of wells for incubation was divided into 11 experimental groups (each consisting of two wells). The experimental groups comprised one brain incubated with (i) DMEM alone, (ii) DMEM plus substance $\mathrm{P}$ (75 ng; SP, S6883, Sigma Chemical Co.), (iii) DMEM plus sGnRH (50 ng; LHRH salmon, L4897, Sigma Chemical Co.), (iv) DMEM plus an antagonist of substance P (125 ng; [D-Pro ${ }^{2}, \mathrm{D}-\operatorname{Trp}^{7,9}$ ]-substance $P$, So145, Sigma Chemical Co.), (v) DMEM plus sGnRH antagonist (100 ng; [D-Phe ${ }^{2,6}$, Pro $^{3}$ ]-LHRH, L4261, Sigma Chemical Co.), (vi) DMEM plus substance $P(75 \mathrm{ng}$ ) plus sGnRH (50 ng), (vii) DMEM plus substance $P$ (75 ng) plus antagonist of substance $P$ (125 ng), (viii) DMEM plus sGnRH (50 ng) plus sGnRH antagonist (100 ng), (ix) DMEM plus PGF $_{2 \alpha}$ (200 ng; Sigma Chemical Co.), (x) DMEM plus PGE (300 ng; Sigma Chemical Co.), (xi) DMEM plus acetylsalicylic acid (ASA; $1 \mu \mathrm{g}$; Sigma Chemical Co.).

The final volume of each well was $1 \mathrm{ml}$. Culture plates were wrapped with aluminium foil and incubated in a shaking water bath $\left(32^{\circ} \mathrm{C}\right)$, set at 30 revolutions $\min ^{-1}$. The medium of one well of each experimental group was removed after $1 \mathrm{~h}$ and $3 \mathrm{~h}$ of incubation. The incubation medium samples and the brains were immediately stored at $-80^{\circ} \mathrm{C}$ until use. In addition, the experiments were repeated in the absence of brains. Tests on five parallel incubation sets were carried out. Preliminary evidence led to the choice of incubation conditions and the minimum effective dose of the substances used in the present study (data not shown).

\section{Determination of aromatase activity}

Aromatase activity was determined in the same brains used for incubation in vitro, as reported by Schumacher and Balthazar (1987) and Zerani et al. (1992). The brains were weighed and homogenized in cold buffer $\left(50 \mu \mathrm{mg}^{-1}\right.$ fresh tissue; $20 \mathrm{mmol} \mathrm{K}_{2} \mathrm{HPO}_{4} 1^{-1}, 1 \mathrm{mmol}$ EDTA $1^{-1}, 3 \mathrm{mmol}$ $\mathrm{NaN}_{3} 1^{-1}, 10 \%$ glycerol $(\mathrm{v} / \mathrm{v}), 10 \mathrm{mmol} \beta$-mercaptoethanol $\mathrm{I}^{-1}, \mathrm{pH}$ 7.4). Homogenates were immediately frozen in an acetone-dry ice bath $\left(-80^{\circ} \mathrm{C}\right)$. For the assay, $200 \mu \mathrm{l}$ of the total homogenate was thawed, and immediately $500 \mu \mathrm{l}$ of the homogenization buffer containing 200000 d.p.m. of $[1,2,6,7-$ ${ }^{3} \mathrm{H}$ ]testosterone (Amersham International, Amersham; specific activity $70-105 \mathrm{Ci} \mathrm{mmol}{ }^{-1}$ ) and $2.5 \mathrm{mg} \mathrm{NADPH} \mathrm{ml}^{-1}$ were added to the incubation tubes. Homogenates were put in a shaking bath $\left(20^{\circ} \mathrm{C}\right)$ at 30 revolutions $\min ^{-1}$ for $15 \mathrm{~min}$. The samples were immediately stored at $-20^{\circ} \mathrm{C}$. Steroids were extracted with $5 \mathrm{ml}$ diethyl ether. Extracts were dried under a flow of nitrogen and resuspended in $500 \mu \mathrm{l}$ of radioimmunoassay buffer $\left(74.5 \mathrm{mmol} \mathrm{Na} \mathrm{HPO}_{4} \mathrm{l}^{-1}, 12.5 \mathrm{mmol}\right.$ EDTA- $\mathrm{Na}_{2} \cdot 2 \mathrm{H}_{2} \mathrm{O} 1^{-1}, 0.1 \%$ gelatine, $0.1 \% \mathrm{NaN}_{3}, \mathrm{pH} 7.5$ ). Radioimmunoassay buffer $(500 \mu \mathrm{l})$ containing oestradiolspecific antiserum in excess (compounds that crossreact more than $0.1 \%$ : oestrone, $1.6 \%$; oestradiol, $0.5 \%$ ) was added to duplicate samples $(200 \mu \mathrm{l})$. The mixtures were incubated at $4^{\circ} \mathrm{C}$ for $16 \mathrm{~h}$. The $\left[{ }^{3} \mathrm{H}\right]$ oestradiol-bound antiserum was separated with $500 \mu \mathrm{l}$ of a charcoal-dextran $(0.45 \%$ and $0.5 \%$, respectively) suspension and added to $3 \mathrm{ml}$ of Aqualyte (J. T. Baker, Deventer). The radioactivity was counted in a liquid scintillation system LS 1801 (Beckman Instruments, Fullerton, CA). The radioactivity of the control tubes (blanks) containing buffer, $\mathrm{NADPH}_{2}$ and tracer, but no tissue homogenate, was subtracted from the final values.

\section{Determination of prostaglandins and sex steroids}

A radioimmunoassay (Gobbetti et al., 1993) was used to detect $\mathrm{PGF}_{2 \alpha}$ and $\mathrm{PGE}_{2}$, progesterone, androgens and oestradiol in incubation media. Intra-assay and interassay coefficients of variation and minimum detectable doses were: $\mathrm{PGF}_{2 \alpha}, 10 \%$, $16 \%$, $11 \mathrm{pg} ; \mathrm{PGE}_{2}, 9 \%, 13 \%, 8 \mathrm{pg}$; progesterone, $9 \%, 12 \%$, $7 \mathrm{pg}$; androgens, $8 \%, 12 \%, 13 \mathrm{pg}$; and oestradiol, $6 \%, 12 \%$, $7 \mathrm{pg}$, respectively. The recoveries of added tritiated hormones were: $\mathrm{PGF}_{2 \alpha^{\prime}} 81.6 \% ; \mathrm{PGE}_{2}, 79.3 \%$; progesterone, $86.3 \%$; testosterone, $85.1 \%$; and oestradiol, $88.6 \%$, respectively. $\mathrm{PGF}_{2 \alpha^{\prime}}$ progesterone, testosterone and oestradiol antisera were provided by G. F. Bolelli and F. Franceschetti (CNR Physiopathology of Reproduction Service, University of Bologna, Bologna). The $\mathrm{PGE}_{2}$ antiserum was purchased from Cayman Chemical Co. (Ann Arbor, MI). As testosterone was not separated from $5 \alpha$-dihydrotestosterone and therefore the antiserum used was not specific, the data are expressed as androgens. Tritiated prostaglandins and sex steroids were purchased from Amersham; non-radioactive compounds were supplied by Sigma Chemical Co.

\section{Statistical analysis}

Analysis of variance (ANOVA) followed by Duncan's multiple range test was used to analyse the data (Duncan, 1955; Sokal and Rohlf, 1981). Correlation coefficients were calculated as described by Scossiroli and Palenzona (1979).

\section{Results}

\section{Incubation of brains}

A comparison of the basal release of the various hormones measured from lizard brains in vitro reveals that during the 

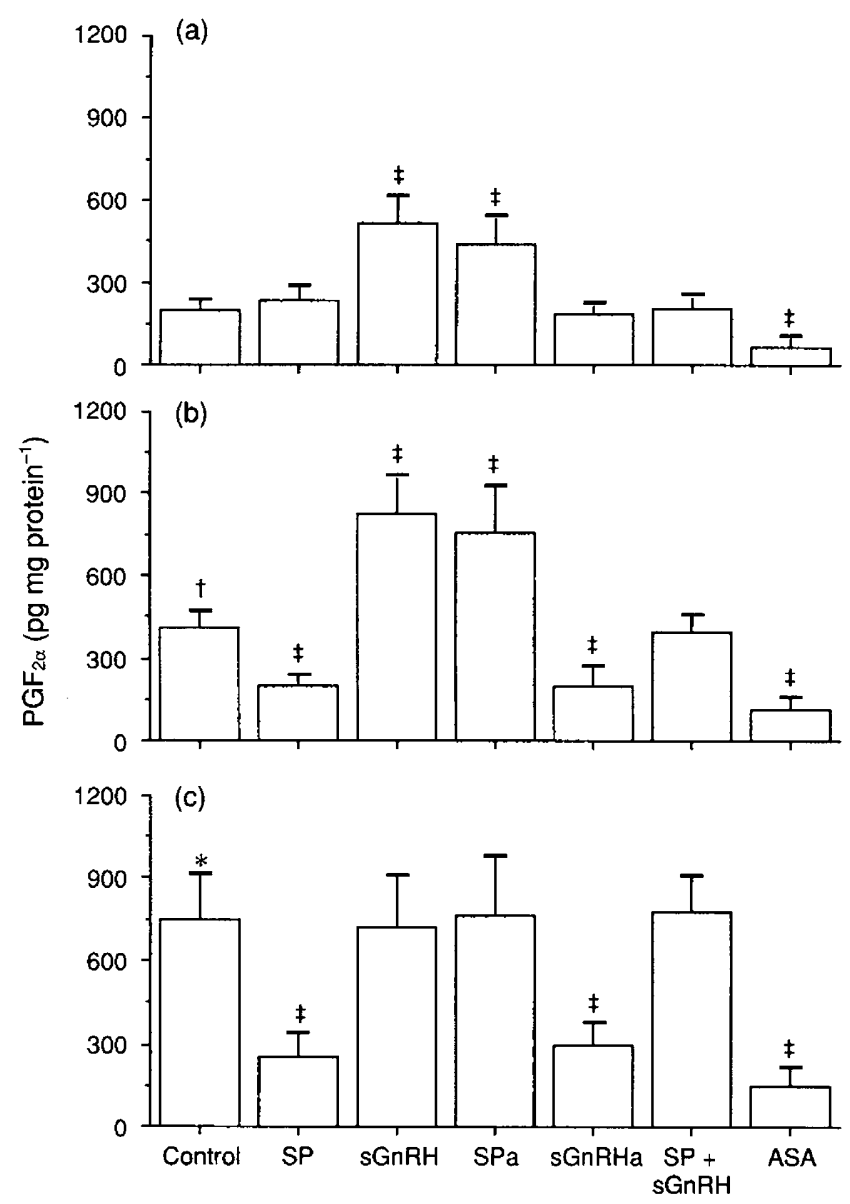

Fig. 1. Effects of substance $P(S P)$, salmon GnRH (sGnRH), SP antagonist $(\mathrm{SPa}), \mathrm{sGnRH}$ antagonist ( $\mathrm{sGnRHa}$ ), $\mathrm{SP}$ plus $s \mathrm{GnRH}$, and acetylsalicylic acid (ASA) on the release in vitro of $\mathrm{PGF}_{2 \alpha}$ from the brain of the male lizard Podarcis sicula sicula, at different reproductive phases: (a) the fighting phase (April); (b) the mating phase (May); and (c) the refractory phase (June). Values are means of five determinations $\pm \mathrm{SD}$. ${ }^{*} P<0.01$ versus April and May, ${ }^{\dagger} P<0.01$ versus April, ${ }^{\ddagger} P<0.01$ versus control (Duncan’s multiple range test).

refractory phase (June), the amount of $\mathrm{PGF}_{2 \alpha}$ and oestradiol released was significantly higher $(P<0.01)$ than during the fighting (April) and mating (May) phases (Figs 1, 2); the release of these two hormones was positively correlated $(r=0.82$; d.f. $=13 ; P<0.001)$. Conversely, the release of $\mathrm{PGE}_{2}$ and androgens were least $(P<0.01)$ in the refractory phase, while androgen release was at its greatest $(P<0.01)$ during the fighting phase (Figs 3,4). There was therefore an inverse correlation between androgens and oestradiol $(r=-0.88$; d.f. $=13 ; P<0.001)$ and between androgens and $P G_{2 \alpha}$ $(r=-0.85 ;$ d.f. $=13 ; P<0.001)$. During the mating phase the amount of $\mathrm{PGF}_{2 \alpha}$ and oestradiol released was greater $(P<0.01)$ than in the fighting phase, and the amount of progesterone released was higher $(P<0.01)$ at this time than in the other two phases (Fig. 5).

A comparison of the effects of the various agents on the release of hormones measured from the lizard brain in vitro reveals that during the mating and refractory phases substance $P$ decreased $(P<0.01)$ the amount of $\mathrm{PGF}_{2 \alpha}$ and oestradiol released (Figs 1,2$)$ and increased $(P<0.01)$ the
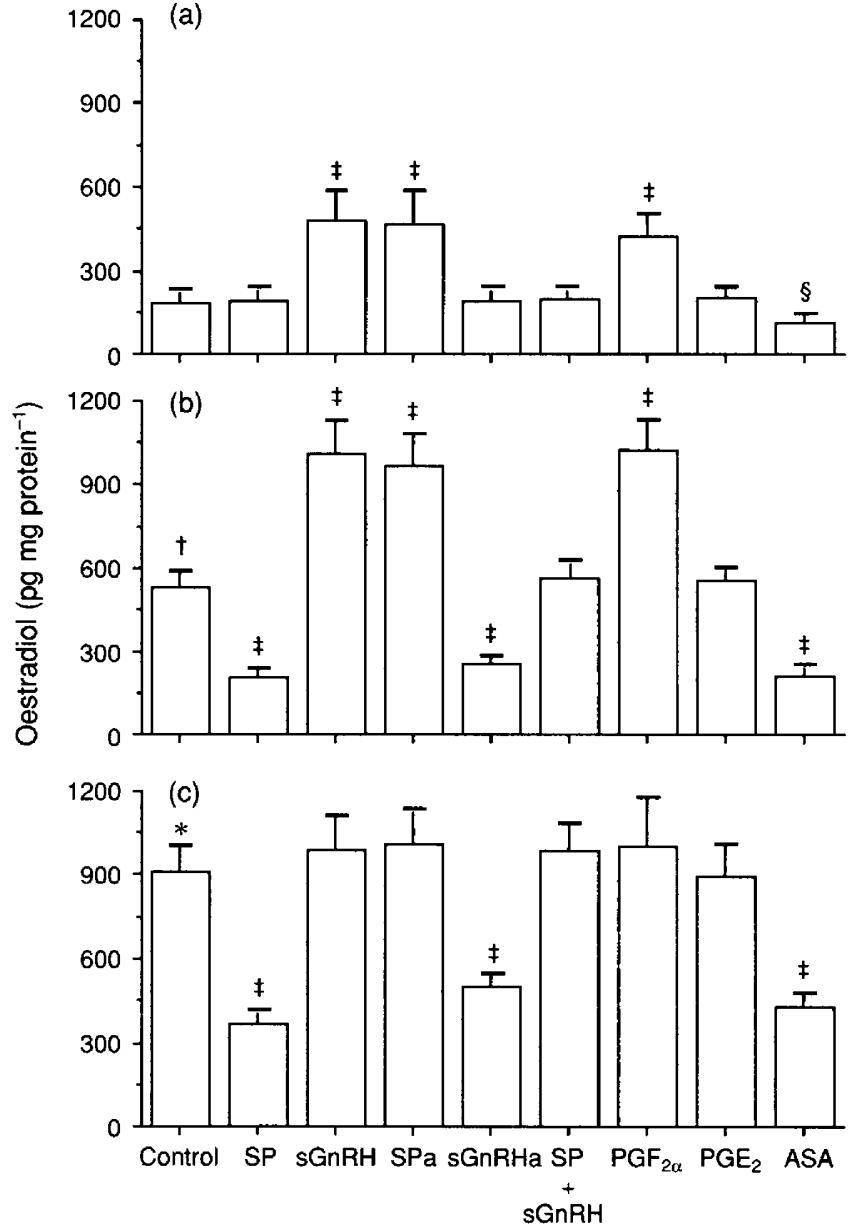

Fig. 2. Effects of substance $P$ (SP), salmon GnRH (sGnRH), SP antagonist (SPa), sGnRH antagonist (sGnRHa), SP plus sGnRH, $\mathrm{PGF}_{2 \alpha^{\prime}} \mathrm{PGE}_{2}$ and acetylsalicylic acid (ASA) on the release in vitro of oestradiol from the brain of the male lizard Podarcis sicula sicula, at different reproductive phases: (a) the fighting phase (April); (b) the mating phase (May); and (c) the refractory phase (June). Values are means of five determinations $\pm \mathrm{SD} .{ }^{*} P<0.01$ versus April and May, ${ }^{\dagger} P<0.01$ versus April, ${ }^{\ddagger} P<0.01,{ }^{5} P<0.05$ versus control (Duncan's multiple range test).

release of androgens (Fig. 4). Conversely, during the fighting and mating phases $\mathrm{sGnRH}$ increased $(P<0.01)$ the release of $\mathrm{PGF}_{2 \alpha}$ and oestradiol (Figs 1,2$)$ and decreased $(P<0.01)$ the release of androgens (Fig. 4). These two neuropeptides alone and in combination increased $(P<0.01)$ the release of $\mathrm{PGE}_{2}$ and progesterone during the mating phase (Figs 3, 5). Substance $P$ plus its antagonist and sGnRH plus sGnRH antagonist did not affect the basal release of any hormones (data not shown).

$\mathrm{PGF}_{2 \alpha}, \mathrm{PGE}_{2}$, progesterone, androgens and oestradiol were not detected in incubation samples in the absence of brain tissue (data not shown).

\section{Aromatase activity}

The quantity of labelled oestradiol produced from tritiated testosterone was greater $(P<0.01)$ in the refractory phase 

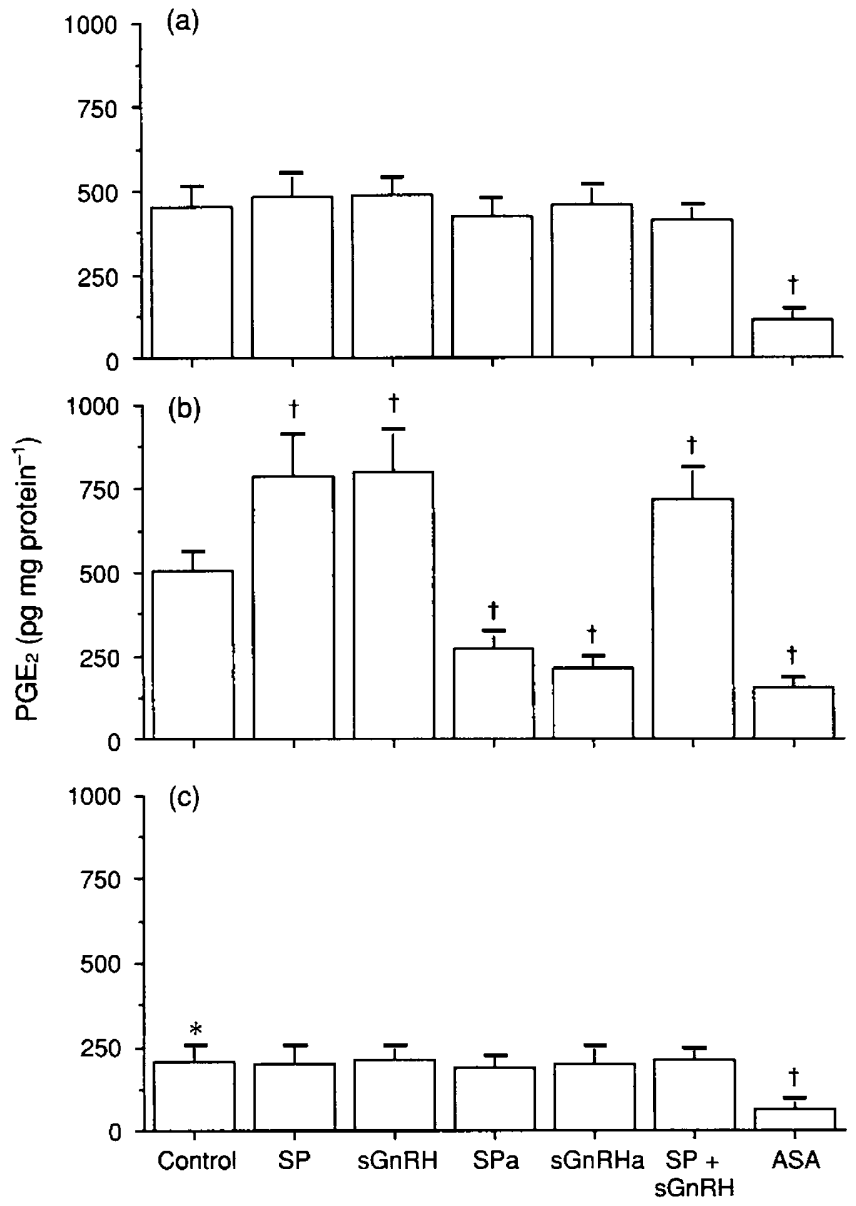

Fig. 3. Effects of substance $P$ (SP), salmon $\mathrm{GnRH}$ (sGnRH), SP antagonist ( $\mathrm{SPa}$ ), sGnRH antagonist ( $\mathrm{sGnRHa)}$ ) SP plus $\mathrm{sGnRH}$, and acetylsalicylic acid (ASA) on the release in vitro of $\mathrm{PGE}_{2}$ from the brain of the male lizard Podarcis sicula sicula, at different reproductive phases: (a) the fighting phase (April); (b) the mating phase (May); and (c) the refractory phase (June). Values are means of five determinations \pm SD. ${ }^{*} P<0.01$ versus April and May, ${ }^{\dagger} P<0.01$ versus control (Duncan's multiple range test).

than in the other two phases, and higher $(P<0.01)$ in the mating than in the fighting phase. This finding correlated significantly with the changes in the basal release of oestradiol $(r=0.94 ;$ d.f. $=13 ; P<0.001)$ and $\mathrm{PGF}_{2 \alpha}(r=0.92$; d.f. $=13 ; P<0.001)$, and was negatively correlated with the basal release of androgens $(r=-0.84 ;$ d.f. $=13 ; P<0.001)$ (Fig. 6).

The quantity of labelled oestradiol produced from tritiated testosterone was decreased $(P<0.01)$ by substance $P$ in the mating and refractory phases. Conversely, in the fighting and mating phases $\mathrm{sGnRH}$ increased $(P<0.01)$ the production of tritiated oestradiol. The antagonists of substance $\mathrm{P}$ and $\mathrm{sGnRH}$ showed opposite effects. The effects of $\mathrm{PGF}_{2 \alpha}$ on the production of $\left[{ }^{3} \mathrm{H}\right]$ oestradiol were similar to those found for $\mathrm{sGnRH}$. ASA decreased the conversion of $\left[{ }^{3} \mathrm{H}\right]$ testosterone into $\left[{ }^{3} \mathrm{H}\right]-$ oestradiol in all phases (Fig. 6). Substance $P$ plus sGnRH, substance $P$ plus substance $P$ antagonist, $s G n R H$ plus $s G n R H$ antagonist and $\mathrm{PGE}_{2}$ did not affect $\left[{ }^{3} \mathrm{H}\right]$ oestradiol values (data not shown).
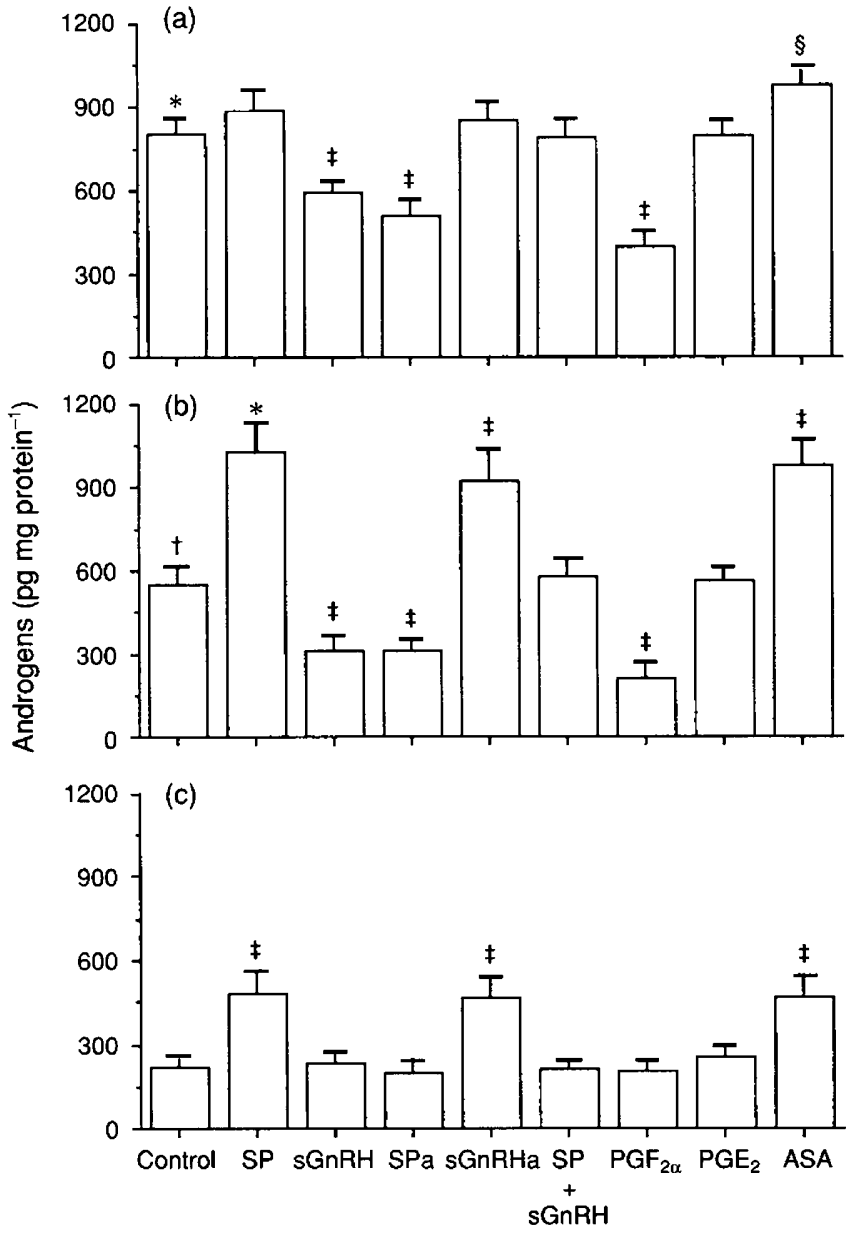

Fig. 4. Effects of substance $P$ (SP), salmon GnRH (sGnRH), SP antagonist $(\mathrm{SPa}), \mathrm{sGnRH}$ antagonist $(\mathrm{s} \mathrm{GnRHa}), \mathrm{SP}$ plus $\mathrm{sGnRH}$, $\mathrm{PGF}_{2 \alpha^{\prime}} \mathrm{PGE}_{2}$, and acetylsalicylic acid (ASA) on the release in vitro of androgens from the brain of the male lizard Podarcis sicula sicula, at different reproductive phases: (a) the fighting phase (April); (b) the mating phase (May); and (c) the refractory phase (June). Values are means of five determinations $\pm \mathrm{SD} .{ }^{*} p<0.01$ versus May and June, ${ }^{\dagger} P<0.01$ versus June, ${ }^{\ddagger} P<0.01,{ }^{5} P<0.05$ versus control (Duncan's multiple range test).

\section{Discussion}

This is the first report that shows that during the various phases of the reproductive period of the male lizard $P$. s. sicula different amounts of prostaglandins and sex steroids and various degrees of aromatase activity occur in the brain. In particular, $\mathrm{PGF}_{2 \alpha}$ and oestradiol release, and aromatase activity exhibit maximum values during the refractory phase (June), confirming for this reptile the relationship between PGF $_{2 \alpha}$ and oestradiol that has been found in two amphibian species: the anuran water frog Rana esculenta (Gobbetti and Zerani, 1991, 1992a, b) and the urodele crested newt Triturus carnifex (Gobbetti and Zerani, 1992b; Gobbetti et al., 1992). This relationship between these two hormones is supported by the positive correlation among $\mathrm{PGF}_{2 \alpha}$, oestradiol and aromatase activity. The high amount of oestradiol released could be responsible for interrupting the reproductive processes (refractory phase), when the environmental cues are still favourable 

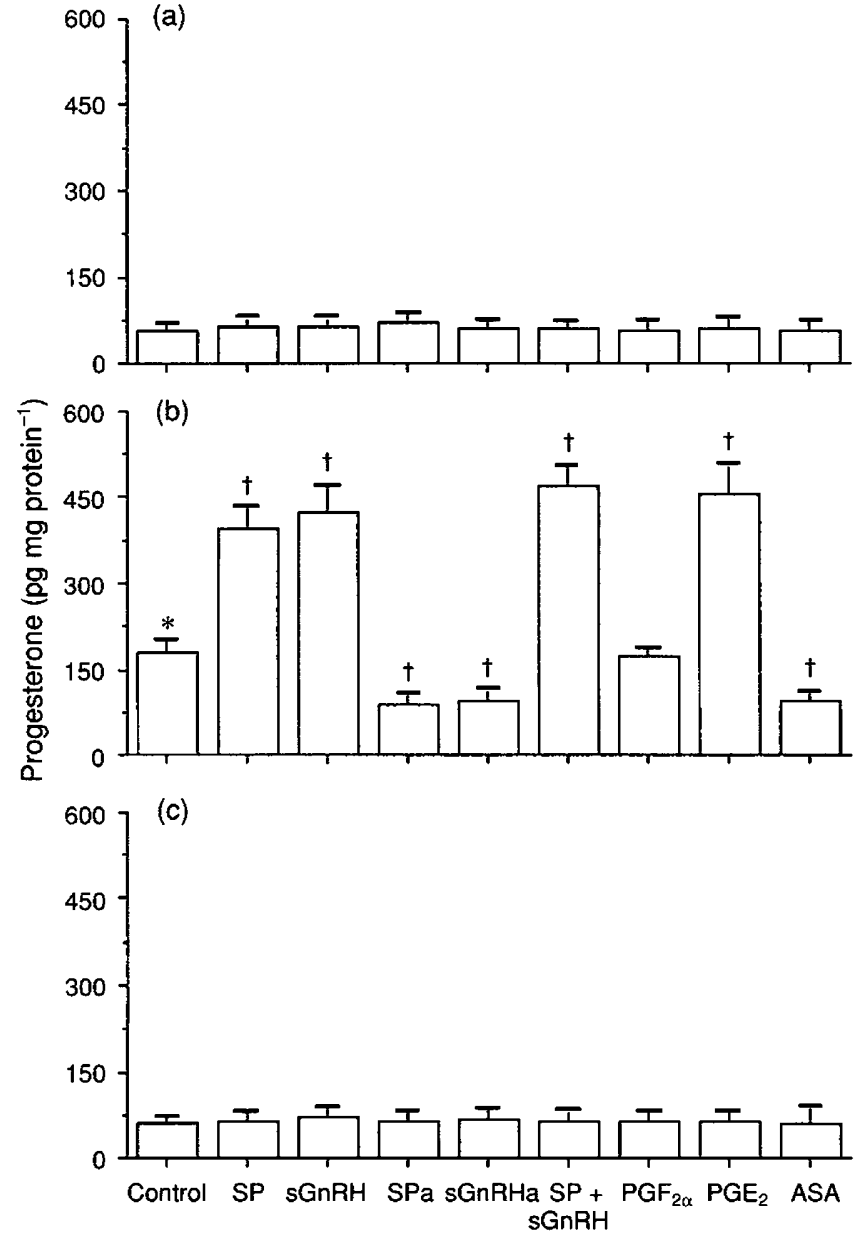

Fig. 5. Effects of substance $P(S P)$, salmon GnRH (sGnRH), SP antagonist ( $\mathrm{SPa}$ ), sGnRH antagonist (sGnRHa), SP plus sGnRH, $\mathrm{PGF}_{2 \alpha^{\prime}}, \mathrm{PGE}_{2}$, and acetylsalicylic acid (ASA) on the release in vitro of progesterone from the brain of the male lizard Podarcis sicula sicula, at different reproductive phases: (a) the fighting phase (April); (b) the mating phase (May); and (c) the refractory phase (June). Values are means of five determinations $\pm \mathrm{SD}$. ${ }^{*} P<0.01$ versus April and June, ${ }^{\dagger} P<0.01$ versus control (Duncan's multiple range test).

for reproduction. This adaptive mechanism would prevent the occurrence of newly hatched lizards in early autumn, as suggested by Angelini et al. (1986). The lizard brain in vitro released the greatest amounts of androgens during the fighting phase (April), confirming the role of androgens in regulating the aggressive behaviour of males, which in this phase are engaged in fights with the other males (Ciarcia et al., 1986). The physiological significance of the different amounts of $\mathrm{PGE}_{2}$ and progesterone released during the various phases of reproduction is, at present, difficult to interpret.

Various forms of GnRH have been found in reptiles: sGnRH (Licht and Porter, 1987), chicken GnRH-I (King and Millar, 1987), and chicken GnRH-II (Sherwood and Whittier, 1988). These three forms of GnRH have been found in the lizard P. $s$. sicula (Powell et al., 1986) and sGnRH causes an increase in the plasma concentration of testosterone in the male of this lizard (Ciarcia et al., 1989), while in the female an analogue of $\mathrm{GnRH}$ exhibits a direct effect on progesterone release by follicles
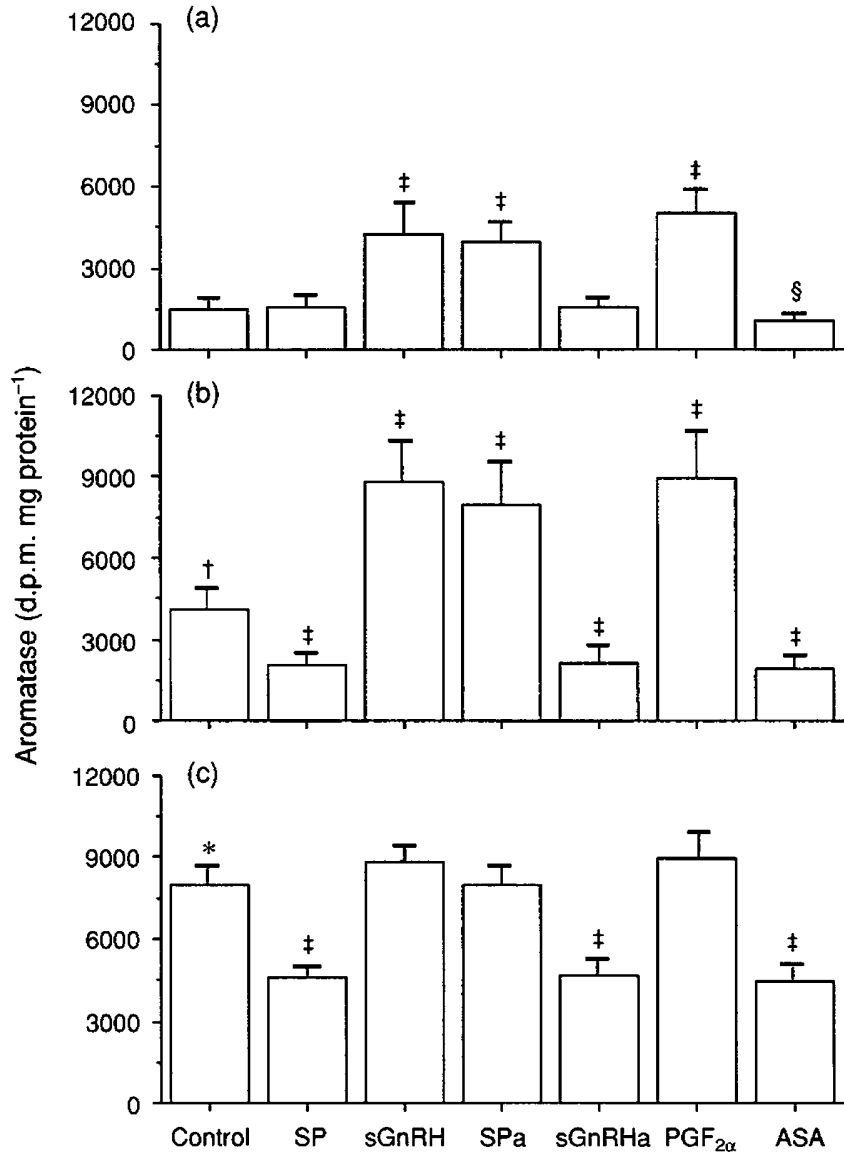

Fig. 6. Effects of substance $P$ (SP), salmon $\mathrm{GnRH}$ (sGnRH), SP antagonist ( $\mathrm{SPa}$ ), sGnRH antagonist (sGnRHa), $\mathrm{PGF}_{2 \alpha}$ and acetylsalicylic acid (ASA) on aromatase activity (conversion of $\left[{ }^{3} \mathrm{H}\right]$ testosterone into $\left[{ }^{3} \mathrm{H}\right]$ oestradiol) in vitro in the brain of the male lizard Podarcis sicula sicula, at different reproductive phases: (a) the fighting phase (April); (b) the mating phase (May); and (c) the refractory phase (June). Values are means of five determinations $\pm \mathrm{SD}$. ${ }^{*} P<0.01$ versus April and May, ${ }^{\dagger} P<0.01$ versus $A$ pril, ${ }^{\ddagger} P<0.01,{ }^{5} p<0.05$ versus control (Duncan's multiple range test).

(Varriale et al., 1986). Substance $\mathrm{P}$ has been found in several reptiles, such as Alligator mississipiensis (Wang et al., 1992), Galliota galloti (Bello et al., 1991), Chrysemys picta (Koste et al., 1980), Lacerta sp. and Testudo kleinmani (Lembeck et al., 1985) but nothing is known about the function of this neuropeptide in the regulation of prostaglandin and sex steroid concentrations in reptiles.

The present data on the effects in vitro of $\mathrm{sGnRH}$ and substance $P$ in the brain of $P$. s. sicula suggest an opposite mechanism of action for these two neuropeptides in the regulation of release of prostaglandins and sex steroids. sGnRH induces an increase in oestradiol release and a decrease in the release of androgens probably by increasing the release of $\mathrm{PGF}_{2 \alpha}$, which then activates aromatase activity. In contrast, SP induces a decrease in oestradiol release and an increase in the release of androgens by decreasing the release of $\mathrm{PGF}_{2 \alpha^{\prime}}$ which attenuates aromatase activity (as confirmed by ASA treatment). These opposite mechanisms attributed to $s \mathrm{GnRH}$ and SP are validated by the opposite effects of their antagonists and by the lack of effect following the treatment with substance $P$ 


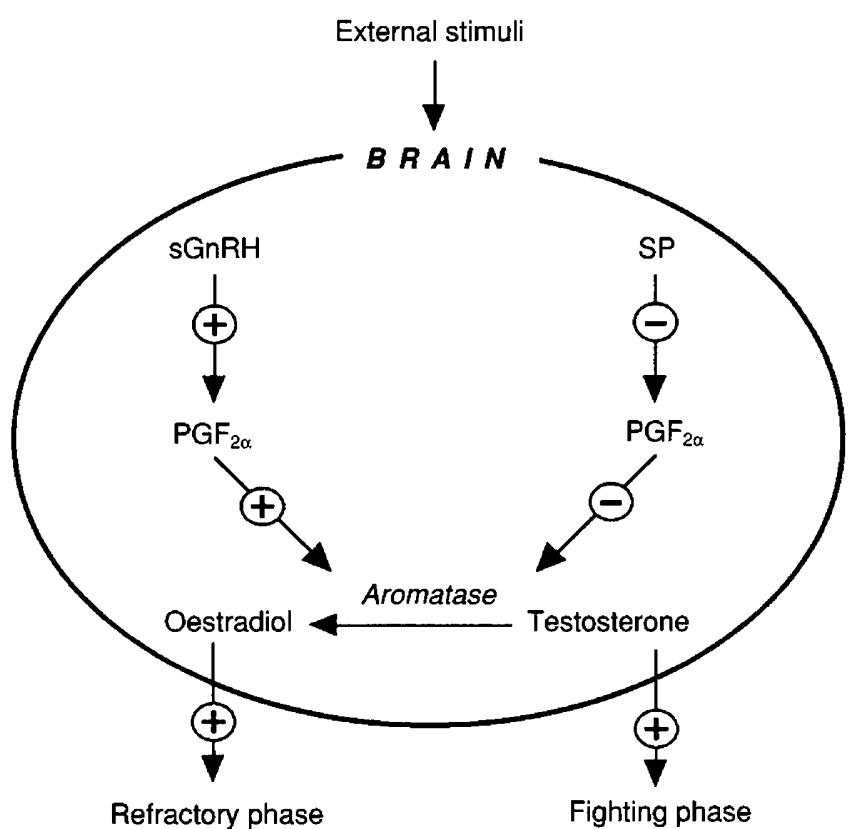

Fig. 7. Possible mechanisms of action of salmon GnRH (sGnRH) and substance $\mathrm{P}(\mathrm{SP})$ in the regulation of reproduction in the brain of the male lizard Podarcis sicula sicula.

plus sGnRH. These findings suggest different roles for these two neuropeptides in the reproductive processes of the male P. s. sicula.

The regulation of the refractory phase seems to involve the release of oestradiol by $\mathrm{sGnRH}$, which is one of the factors that induces the cessation of reproductive activity, as reported above (Angelini et al., 1986). sGnRH fails to increase $\mathrm{PGF}_{2 \alpha}$, oestradiol and aromatase activity in the refractory phase, probably because in this phase the lizard brain expresses the highest values for $\mathrm{PGF}_{2 \alpha}$ oestradiol and aromatase activity, so that the additional stimulus does not affect these patterns. This hypothesis is supported by the results obtained by the sGnRH antagonist, which in the refractory phase decreases $\mathrm{PGF}_{2 \alpha}$, oestradiol and aromatase activity. SP could play a role in regulating the fighting behaviour of $P$. s. sicula by releasing androgens, which are the main factor inducing this reproductive behaviour, as reported above (Ciarcia et al., 1986). Just as sGnRH does not exhibit effects in vitro in the refractory phase, substance $\mathrm{P}$ fails to decrease $\mathrm{PGF}_{2 \alpha}$ and aromatase activity and to increase androgens in the fighting phase, probably because in this phase the brain expresses the lowest values for $\mathrm{PGF}_{2 \alpha}$ and aromatase activity and the highest amounts of androgens so that the additional stimulus of substance $P$ is ineffective.

Finally, $s G n R H$ and substance $P$ cause an increase in progesterone release in the mating phase (May), and this effect is mediated by $\mathrm{PGE}_{2}$. However, at present, the significance of this phenomenon is unclear.

In summary, sGnRH and SP could have different roles in reproductive processes, with opposite mechanisms, in the central nervous system of the male $P$. s. sicula (see Fig. 7). Substance $\mathrm{P}$ appears to be involved in beginning reproductive behaviour (fighting phase), and $\mathrm{sGnRH}$ in terminating it (refractory phase).
The authors would like to thank J. Burge, of the Camerino University Institute of Linguistics, for help with English. This work was supported by a grant from Ministero Università Ricerca Scientifica e Tecnologica.

\section{References}

Angelini F, Botte $V$ and Boschi $R$ (1980) The relation of the reproductive cycle of Podarcis s. sicula Raf. (Reptilia, Lacertidae). Influence of the refractory period on the spring time testicular activity Monitore Zologico Italiano (NS) 14 27-39

Angelini F, Ciarcia G, Picarello O and Botte V (1981) Are the gonads implied in postreproductive refractoriness determinism in the lizard, Podarcis s. sicula? Rendiconti della Accademia Nazionale dei Lincei 71 210-213

Angelini F, Ciarcia G, Picarello O, Botte V and Pagano M (1986) Sex steroids and reproductive refractoriness in the lizard Podarcis s. sicula Bollettino di Zoologia $5359-62$

Arisawa M, De Palatis L, Ho R, Snyder GD, Yu WH, Pan G and McCann SM (1990) Stimulatory role of substance $P$ on gonadotropin release in ovariectomized rats Neuroendocrinology 5 523-529

Bello AR, Marti E, Lancha A, Beauvillain JC, Tramu G and Batista MAP (1991) Presence of substance $P$ and angiotensin II in corticotropic cells of the lizard Galliota gallotri: immunochemical study in the adult and during ontogenesis Neuroendocrinology 53 614-622

Callard GV, Petro Z and Ryan KJ (1978) Phylogenetic distribution of aromatase and other androgen converting enzymes in the central nervous system Endocrinology 103 2283-2290

Ciarcia G, Angelini F, Polzonetti A, Zerani M and Botte V (1986) Hormones and reproduction in the lizard Podarcis s. sicula Raf. In Endocrine Regulation as Adaptative Mechanisms to the Environment pp 95-102 Eds I Assenmacher and I Boissin. Editions du CNRS, Paris

Ciarcia G, Paolucci M and Botte V (1989) Effects of gonadotrophin-releasing hormone variants on reproductive organs and plasma testosterone in the male lizard Podarcis s. sicula Journal of Neuroendocrinology 1 205-208

Duncan DB (1955) Multiple range and multiple F test Biometrics 11 I-42

Gobbetti A and Zerani M (1991) Gonadotropin-releasing hormone stimulates biosynthesis of prostaglandin $\mathrm{F}_{2 \alpha}$ by the interrenal gland of the water frog, Rana esculenta, in vitro General and Comparative Endocrinology 84 434-439

Gobbetti A and Zerani M (1992a) A possible involvement of prostaglandin $F_{2 \alpha}$ $\left(\mathrm{PGF}_{2 \alpha}\right)$ in Rana esculenta ovulation: effects of mammalian gonadotropinreleasing hormone on in vitro $\mathrm{PGF}_{2 \alpha}$ and $17 \beta$-estradiol production from ovary and oviduct General and Comparative Endocrinology 87 162-170

Gobbetti A and Zerani M (1992b) Mammalian GnRH involvement in prostaglandin $\mathrm{F}_{2 \alpha}$ and sex steroid hormones testicular release in two amphibian species: the anuran water frog, Rana esculenta and the urodele crested newt Triturus camifex General and Comparative Endocrinology 87 240-248

Gobbetti A, Zerani M and Bellini-Cardellini L (1992) Relationships among mammalian gonadotropin-releasing hormone, prostaglandins, and sex steroids in the brain of the crested newt Triturus carnifex Prostaglandins $\mathbf{4 5}$ 159-166

Gobbetti A, Zerani M, Di Fiore MM and Botte V (1993) Prostaglandins and sex steroids from reptilian (Podarcis sicula sicula) ovarian follicles at different developmental stages Zoological Sciences 100, 321-328

Jung-Testas I, Hu ZY, Baulieu EE and Robel P (1989) Steroid synthesis in rat brain cell cultures Joumal of Steroid Biochemistry 34 511-519

King JA and Millar RP (1987) Phylogenetic diversity of LHRH. In Contraceptive and Therapeutic Applications Vol. 2 pp 53-73 Eds BH Vichery and JJ Nestor MTP Limited Press, Lancaster

Koste GEA, Reiner A and Karten HJ (1980) Substance P like immunoreactivity in cerebellar mossy fibers and terminals in the red-eared turtle Chrysemys scripta elegans Neuroscience 5 903-914

Lembeck F, Bernatzky G, Gamse R and Saria A (1985) Characterization of substance $P$-like immunoreactivity in submammalian species by high performance liquid chromatography Peptides 6 (Supplement 3) 231-236

Licht P and Porter DA (1987) Role of gonadotropin-releasing hormone in regulation of gonadotropin secretion from amphibian and reptilian pituitaries. In Hormones and Reproduction in Fishes, Amphibians and Reptiles pp 61-85 Eds DO Norris and RE Jones. Raven Press, New York

Pitzel L, Jarry $\mathbf{H}$ and Wuttke W (1991) Effects of substance-P and Neuropeptide- $Y$ on in vitro steroid release by porcine granulosa and luteal cells Endocrinology 129 1059-1065 
Powell RC, King JA and Millar RP (1985) $\left[\mathrm{Trp}^{7}, \mathrm{Leu}^{8}\right] \mathrm{LH}-\mathrm{RH}$ in reptilian brain Peptides 6 223-227

Powell RC, Ciarcia G, Lance V, Millar RP and King JA (1986) Identification of diverse molecular forms of $\mathrm{GnRH}$ in reptile brain Peptides 7 1101-1108

Schumacher $\mathbf{M}$ and Balthazar J (1987) Neuroanatomical distribution of testosterone-metabolizing enzymes in the Japanese quail Brain Research $\mathbf{4 2 2}$ 137-148

Scossiroli RE and Palenzona DL (1979) Manuale di Biometria. Zanichelli, Bologna Sherwood NM and Whittier JM (1988) Gonadotropin-releasing hormone from brains of reptiles: turtles (Pseudemys scripta) and snakes (Thamnophis sirtalis parietalis) General and Comparative Endocrinology $69319-327$

Sokal RR and Rohlf FJ (1981) Biometry (2nd Edn) pp 208-371. Freeman, San Francisco

Tokarz RR and Crews D (1981) Effects of prostaglandins on sexual receptivity in the female lizard, Anolis carolinensis Endocrinology 109 451-457
Tsai PS and Licht P (1993) Differential distribution of chicken-I and chicken-II GnRH in the turtle brain Peptides 14 221-226

Varriale B, Pierantoni R, Di Matteo L, Minucci S and Chieffi G (1986) In vitro GnRHa (HOE766) effects on ovarian steroid-output in nonmammalian vertebrates Bollettino di Zoologia 53 381-383

Wang Y, O'Harte F and Conlon JM (1992) Structural characterization of tachykinins (neuropeptide $Y$, neurokinin $A$ and substance $P$ ) from a reptile, Alligator mississipiensis General and Comparative Endocrinology 88 277-286

Whittier JM and Crews D (1986) Effects of prostaglandin $F_{2 \alpha}$ on sexual behaviour and ovarian function in female garter snakes (Thamnophis sirtalis parietalis) Endocrinology 119 787-792

Zerani M, Amabili F and Gobbetti A (1992) Plasma testosterone and 17 $\beta$ estradiol concentrations, and aromatase activity, during courtship in male Triturus carnifex Hormones and Behaviour 26 56-61 